\title{
To Model a Psychiatric Disorder in Animals: Schizophrenia As a Reality Test
}

\author{
Barbara K. Lipska, Ph.D. and Daniel R. Weinberger, M.D.
}

\begin{abstract}
Animal modeling has been instrumental in dissecting pathophysiological mechanisms and designing more effective therapies in many areas of medicine but not so in psychiatry. The critical obstacle in modeling psychiatric disorders has been limited information about their origin and underlying neural mechanisms. Recently, with rapidly growing knowledge about the neurobiology and genetics of psychiatric disorders, animal models of these diseases are gaining popularity in psychiatric research. New models of schizophrenia mimic biological phenomena associated with
\end{abstract}

the clinical condition, particularly developmental changes in the cortex, abnormalities of glutamate neurotransmission, and genetic characteristics of selected behavioral traits. The biological fidelity of some aspects of these new models suggests that they will be useful in the development of new therapies, in identifying candidate genes, and in providing new insights about pathophysiology and etiology.

[Neuropsychopharmacology 23:223-239, 2000]

(C) 2000 American College of Neuropsychopharmacology.

Published by Elsevier Science Inc. All rights reserved.
KEY WORDS: Schizophrenia; Animal models; Neurodevelopment; Glutamate; Genetic models

Animal models are important developments in investigations of the mechanisms underlying a human disease and the design of new treatments. This is true for many diseases, but generally not for mental disorders, whose modeling in experimental animals has often been regarded as a highly controversial or outright heretic idea. An example of a particularly formidable challenge for animal modeling is schizophrenia, a complex disorder of unknown origin, characterized by abnormalities of uniquely human behaviors in the realms of perception, thinking and the experience of emotions, and whose onset is virtually restricted to young adulthood. Schizophrenia is such an inherently human disease that reproducing its most prominent symptoms-hallucina-

From the Clinical Brain Disorders Branch, Intramural Research Program, National Institute of Mental Health, NIH, IRP, Bethesda, MD.

Address correspondence to: Barbara K. Lipska, CBDB, IRP, NIH, NIMH, Bethesda, MD 20892-1385.

Received March 7, 2000; revised May 1, 2000; accepted May 5, 2000. tions, delusions and thought disorder-in a rodent or even in a non-human primate seems doomed. However, recent new evidence about the neurobiology of the condition has generated new avenues of animal research. In this perspective article, we highlight recent achievements in the efforts to model the neurobiology of schizophrenia in animals, consider limitations inherent in any heuristic animal model of this and probably other psychiatric disorders, and discuss the usefulness of a new generation of animal models for testing particular hypotheses about etiology and pathophysiology of schizophrenia.

\section{TRADITIONAL DOPAMINE-BASED ANIMAL MODELS}

An animal model may represent a disease on three different levels: (1) it may reproduce inducing factor(s) (e.g., a genetic defect and the subsequent pathological processes underlying the disease); (2) it may mimic phenomenology (e.g., an array of symptoms of schizophrenia); and (3) it may predict responsiveness to already available treatments (e.g., antipsychotic drugs). 
Thus, the characteristics of an animal model and its faithfulness vary according to the aspects that it aspires to represent. Models that reconstruct the etiology and pathophysiological mechanisms of the disease are of the highest order of fidelity; they have so-called "construct validity." Models with construct validity usually, though not invariably (see below), possess some degree of face and predictive validity (Kornetsky and Markowitz 1978; McKinney and Moran 1981; Ellenbroek and Cools 1990; Rupniak and Iversen 1993; Costall and Naylor 1995). A good illustration of valid and useful models of complex diseases are genetic models of diabetes and hypertension; for instance, the $\mathrm{db} / \mathrm{db}$ mice model of diabetes (Kobayashi et al. 2000) and the spontaneously hypertensive rat (SHR) (Patel et al. 2000). Unlike these models which faithfully reproduce relatively clear-cut physiological characteristics (e.g., high blood sugar levels or high blood pressure), models of psychiatric disorders face the unique difficulty of simulating much more complex and less easily defined pathophysiology. Traditionally, most animal models of schizophrenia have focused primarily on phenomena linked to dopamine, because the dopaminergic system has been strongly implicated in this disorder, as all effective antipsychotic drugs are antagonists of dopamine receptors, and dopamine agonists induce symptoms that resemble psychosis (Kornetsky and Markowitz 1978; McKinney and Moran 1981; Ellenbroek and Cools 1990; Costall and Naylor 1995, see Table 1).

Some dopamine-based models involve behavioral paradigms that were inspired by antipsychotic (i.e., antidopaminergic) pharmacology but bear no resemblance to schizophrenia (e.g., antagonism of apomorphine-induced emesis). Others reproduce phenomena isomorphic with selected characteristics of schizophrenia such as motor behaviors (e.g., dopamimetic drugsinduced stereotypies) and information processing deficits (e.g., apomorphine-induced prepulse inhibition of startle (PPI) abnormalities) (Braff and Geyer 1990; Costall and Naylor 1995). These dopamine-linked behaviors, although not specific for or uniquely prominent in schizophrenia, can be at least detected and precisely quantified in non-human species and have been useful in screening drugs with a predicted mechanism of action (e.g., dopamine blockade). Thus, models based on perturbing dopamine have no construct validity, limited face validity and relatively good predictive validity. The predictive validity was to be expected given that the models were based on changing dopamine function. However, as "dopamine-in, dopamine-out" models (i.e., models based on direct pharmacological manipulation of the dopaminergic system and tests of behavioral outcome related to dopamine function), they precluded exploring other than dopamine-based mechanisms of the disease and discovering novel antipsychotic therapies; to wit, drugs that emerged as a result of such models all exerted antidopaminergic efficacy. Antidopaminergic drugs, however, although ameliorative of some of the symptoms of schizophrenia, do not cure the disease. It has become increasingly clear that models based on direct manipulations of the dopamine system may have exhausted their heuristic potential and that new strategies need to be developed to provide novel targets for the development of more effective therapeutic agents.

\section{THE SEARCH FOR A HEURISTIC MODEL}

In the context of our current knowledge about schizophrenia, heuristic (i.e., "serving to discover," innovative) models have several goals: (1) to test the plausibility of theories derived from the emerging research data about the disorder; (2) to probe the explanatory power of new biological findings about the disorder; (3) to uncover mechanisms of schizophrenia-like phenomena; and (4) to suggest potential new treatments. Thus, a heuristic model, in contrast to a traditional dopaminebased model, needs to evince other schizophrenia-like abnormalities besides the feature that it directly manipulates. For instance, a model based on hippocampal injury would be heuristic if it triggered behavioral and/

Table 1. Clinical Aspects of Schizophrenia and Relevant Behavioral Changes in Animals

\section{Schizophrenia: Clinical Phenomena}

1. Psychotic symptoms

2. Stereotypic behaviors

3. Worsening of psychotic symptoms by NMDA-antagonists

4. Vulnerability to stress

5. Information processing deficits

6. Attentional deficits

7. Cognitive deficits

8. Social withdrawal
Animal Models: Behavioral Changes

Behaviors related to increased dopaminergic transmission:

Dopamimetic-induced hyperlocomotion

Reduced haloperidol-induced catalepsy

Dopamimetic-induced stereotypies

NMDA antagonists-induced locomotion

Stress-induced hyperlocomotion

Sensorimotor gating (PPI, P50) deficits

Deficits in latent inhibition

Impaired performance in delayed alternation and spatial memory tests Reduced contacts with unfamiliar partners 
or molecular changes outside the hippocampus that are associated with schizophrenia, enabled testing the mechanisms underlying the ensuing changes, and predicted novel therapies based on newly discovered mechanisms.

Recently, as interest in schizophrenia research has shifted from a principal focus on dopamine to theories of abnormal neurodevelopment, dysfunction of cortical glutamatergic neurons, and genetic susceptibility, animal models have followed a similar trend. The novel models considered below are either non-pharmacological or based on pharmacological manipulation of a neurotransmitter other than dopamine. Thus, they have ventured off the beaten path of "dopamine-in, dopamine-out" models, and offer the potential of elucidating non-dopamine mechanisms of disease and treatment. All animal models of schizophrenia, however, whether new or old, suffer from a generic problem-lack of a straightforward "litmus test" of fidelity. This is because there is no valid genotype, cellular phenotype or other biological marker that is characteristic of the disorder, and no animal model can fully reproduce the perceptual, cognitive and emotional features of the human illness. In the absence of a pathognomonic marker, a faithful model is expected to reproduce a constellation of behavioral and biological phenomena relevant to schizophrenia. If a model addresses a cluster of relevant changes ranging from anatomical and neurochemical to behavioral and cognitive features, rather than a single or a few non-specific phenomena, then there is a higher probability that the model is heuristic and isomorphic with biological processes related to the human disorder. As new findings about the pathophysiology of schizophrenia emerge, new models increasingly focus on certain cell or tissue phenotypes and a variety of complex behavioral characteristics, in addition to timehonored effects on dopamine related function (see Tables 1 and 2); unfortunately, as shown in the examples below, rarely are multiple phenomena addressed in a single model.

In the following discussion, we examine three approaches to creating animal models related to schizophrenia: (1) neurodevelopmental models, (2) glutamatergic hypofunction models and (3) genetic models. The first approach is based on experimentally induced disruption of brain development that becomes evident in an adult animal in the form of altered brain neurochemistry and aberrant behavior (neurodevelopmental models). These models test hypotheses that schizophrenia is caused by a defect in cerebral development (Lillrank et al. 1995), and in some instances, test whether the effects of early brain damage could remain inconspicuous until after a considerable delay, as appears to be the case in the human condition (Weinberger 1986, 1987; Murray and Lewis 1987; Bloom 1993). Another popular modeling approach involves pharmacological disruption of brain function and behavior via N-methyl-Daspartate (NMDA) antagonists. These models test the hypothesis that dysfunction of glutamate neurotransmission accounts for a variety of schizophrenic phenomena (Javitt and Zukin 1991). Still another effort focuses on the search for susceptibility genes employing modern technologies of genetic engineering (genetic models, see Erickson 1996). These models test the clinical evidence that susceptibility genes account for risk for illness and, together with epigenetic/environmental factors, for phenotypic variation. Characteristically, a majority of these new models, despite the diversity of

Table 2. The Neonatal Ventral Hippocampal Lesion Model: Schizophrenia-like Phenomena

\begin{tabular}{|c|c|c|}
\hline & Neonatal VH Lesion Model & Schizophrenia \\
\hline \multicolumn{3}{|l|}{ Behavioral changes: } \\
\hline & Hyperlocomotion to stress & Stress vulnerability \\
\hline & PPI deficits & PPI deficits \\
\hline & LI deficits & LI deficits \\
\hline & Deficits in delayed alternation tests & Working memory deficits \\
\hline & Reduced social contacts & Social withdrawal \\
\hline \multicolumn{3}{|l|}{ Pharmacological responses: } \\
\hline & Amphetamine-induced hyperactivity & Enhanced symptomatic response \\
\hline & Apomorphine-induced stereotypies & to dopamimetics \\
\hline & Reduced catalepsy to haloperidol & Neuroleptic tolerance \\
\hline & MK-801 and PCP-induced & Enhanced symptomatic \\
\hline \multicolumn{3}{|l|}{ Molecular changes in the prefrontal cortex: } \\
\hline & NAA levels $\downarrow$ & NAA levels $\downarrow$ \\
\hline & GAD67 mRNA $\downarrow$ & GAD67 mRNA $\downarrow$ \\
\hline & BDNF mRNA $\downarrow$ & BDNF mRNA $\downarrow$ \\
\hline
\end{tabular}


their origins, target components of a common neural circuitry implicated in schizophrenia (i.e., the temporolimbic cortices - nucleus accumbens/striatal complex - thalamus - prefrontal cortex. The involvement of this circuitry may account for the overlap in "schizophrenia-like" phenomena at the anatomical, neurochemical or behavioral level that are common to these various models.

\section{NEURODEVELOPMENTAL MODELS}

\section{Testing Etiologic Theories}

Many epidemiological and clinical correlational studies have been carried out in search of early developmental factors that may predispose to schizophrenia. There have been reports linking schizophrenia to obstetrical complications (Woerner et al. 1973; DeLisi et al. 1988; McNiel 1988; Hultman et al. 1997; Dalman et al. 1999), in utero exposure to alcohol (Lohr and Bracha 1989) and severe malnutrition (Susser and Lin 1992). Although many of these data are controversial (for review, see Weinberger 1995), a number of animal models have been designed to test the plausibility that specific gestational factors play a role in the origin of this disorder. These "etiological" models, none of which directly manipulates dopamine, aspire to construct validity and heuristic value because they reproduce putative causes of the disease and theoretically model putative primary pathological mechanisms.

For instance, a gestational malnutrition model (or more precisely, prenatal protein deprivation that begins prior to and continues throughout pregnancy) results in severe permanent changes in the development of the rat brain (for reviews, see Morgane et al. 1993; Brown et al. 1996). Malnutrition affects neurogenesis, cell migration and differentiation, and leads to deviations in normal brain development, including disrupted formation of neural circuits and neurotransmitter systems (Lewis et al. 1979; Cintra et al. 1997). Not suprisingly, malnutrition has been shown to have debilitating effects on cognitive function and learning abilities (Tonkiss and Galler 1990). Thus, to some degree these models mimic certain "face" features of schizophrenia. In contrast to schizophrenia, however, morphological abnormalities are severe and widespread, and the behavioral consequences are varied and inconsistent, perhaps, at least in part, because the impact of malnutrition on brain development is likely to be quite variable and depend on many factors, which have only been explored to a small degree. As a test of the plausibility of the malnutrition theory of schizophrenia this model has limited validity.

Prenatal exposure to influenza virus, another predisposing factor implicated in schizophrenia by several large epidemiological studies (Mednick et al. 1988; Kendell and Kemp 1989; O'Callaghan et al. 1991; Adams et al. 1993), has been shown to induce pyramidal cell disarray in a small subgroup of mice whose mothers were inoculated with the virus (Cotter et al. 1995). This developmental defect is somewhat similar to that reported in two studies in the hippocampi of schizophrenic patients (Conrad et al. 1991; Scheibel and Kovelman 1981). Another recent report indicates that infection with human influenza of day 9 pregnant mice results in defective corticogenesis as indicated by reduced thickness of the neocortex and hippocampus and by significant reductions of cortical Reelin immunoreactivity in the offspring (Fatemi et al. 1999). This model thus reproduces a hypothetical causative factor in schizophrenia and has face validity at least at the level of reduced Reelin expression, a neurobiological finding recently explored in brains of patients with schizophrenia (Impagnatiello et al. 1998). These are intriguing observations, but more conclusive data on the involvement of Reelin in schizophrenia and on the behavioral phenotype of the animal model are required before conclusions about the relevance of this model for schizophrenia can be made.

The plausibility that other, less common, viruses may induce schizophrenia-like changes has also been investigated (Rott et al. 1985; Waltrip et al. 1995). In utero Borna disease virus (BDV), a neurotropic virus with limbic selectivity, damages the hippocampus and prefrontal cortex, and results in complex changes in regional dopamine in rats (Solbrig et al. 1994, 1996a, 1996b; Hornig et al. 1999). While this model may invite further research into the mechanisms involved, notwithstanding convincing evidence of BDV infection in schizophrenia, its relevance to the pathophysiology of schizophrenia seems remote. Another example of a viral model is neonatal infection with lymphocytic choriomeningitis virus (LCMV) which disrupts in adult rats the integrity of $\gamma$-aminobutyric acid (GABA)-ergic neurons and excitatory amino acid systems, both implicated in schizophrenia (Pearce et al. 1996, 1999). The potential face validity of this model at a cellular level makes it particularly attractive because it addresses two theories about the pathophysiology of schizophrenia, vulnerability of GABAergic interneurons to developmental insult and adolescent vulnerability to excitotoxic injury (Benes et al. 1991, 1992; Olney and Farber 1995). Although conceptually appealing, it has yet to address a broader spectrum of aspects of the disorder, and its basic construct, LCMV infection, is of dubious relevance to schizophrenia.

The plausibility of obstetrical and birth complications are difficult to explore in animals because their causes in schizophrenia are unknown. Nevertheless, studies of models of Cesarean birth and of anoxia during birth in rats, report changes in limbic dopamine function of adult animals consistent with hyperresponsiveness of the dopamine system to stimulants (Brake et 
al. 1997a, 1997b; El-Khodor and Boksa 1997, 1998). Surprisingly though, animals born by C-section and not subject to anoxia seem to be even more affected than anoxic rats (El-Khodor and Boksa 1997). If this has bearing on schizophrenia, it would suggest that C-section constitutes a greater risk factor than the more dramatic birth trauma of anoxia. In humans, C-section is generally assumed to involve less stress to the fetus and has not been noted as one of the obstetrical complications linked to schizophrenia. Clearly, more studies are needed to elucidate the mechanisms underlying the C-section-related phenomena in animals.

Until a broader array of schizophrenia-related phenomena is assessed in each of these etiologic models, it is premature to draw firm conclusions about whether any reproduce mechanisms underlying the human disorder. Moreover, the validity of these models is tempered by the lack of convincing evidence for the role of any of these various causative factors in schizophrenia, with the possible exception of influenza. These models illustrate, however, that certain early developmental insults may permanently disrupt brain function in ways that are similar to some of the phenomena reported in schizophrenia.

\section{Testing the Impact of Disrupted Neurogenesis}

Several post mortem studies of schizophrenia have reported variations in cortical cytoarchitecture (Akbarian et al., 1993a, 1993b; Arnold et al. 1991; Kirkpatrick et al. 1999), possibly of developmental nature. These reports have inspired models based on disrupted neurogenesis. These models do not attempt to reproduce specific putative causative factors implicated in schizophrenia, but aspire to face validity at the anatomical level by mimicking cellular aberrations that presumably would follow a disruption of early cortical development analogous to what has been described in some of the human post mortem studies. The heuristic framework of these models is that specific prenatal interruptions of cell maturation would result in relevant biological and behavioral changes as the animal matures. Examples include cortical dysgenesis induced by gestational X-ray irradiation (Rakic 1996; Mintz et al. 1997), in-utero exposure to a mitotic toxin, methylazoxymethanol acetate (MAM), which destroys populations of rapidly dividing neurons (Johnston et al. 1988; Talamini et al. 1998), and systemic administration of nitric oxide synthase (NOS) inhibitors, which interfere with maturation of neurons and synaptogenesis (Black et al. 1999). Animals that have undergone X-ray or MAM manipulations exhibit morphological changes in a broad array of brain structures implicated in schizophrenia, particularly the hippocampus, and frontal and entorhinal cortices. These animals also demonstrate a variety of behavioral alterations such as locomotor hyperactivity, stereotyp- ies, cognitive impairments, and disruption of latent inhibition and PPI, and show electrophysiological abnormalities posited to underlie psychomotor disturbances in schizophrenia (Johnston et al. 1988; Talamini et al. 1998; Moore et al. 1998). Male rats exposed to an NOS inhibitor (L-nitroarginine) between 3-5 days of life show in adulthood locomotor hypersensitivity to amphetamine and deficits in PPI, but similarly treated females were not found to be affected on tese measures (Black et al. 1999). These preliminary results are provocative and invite further research.

Models of aberrant neurogenesis, though the data are limited at this time, appear to have potential heuristic value in discovering mechanisms of specific neural circuit disruptions caused by elimination of maturing neurons. There are a number of areas to be pursued including characterizing critical risk periods (specifically a period corresponding to the second trimester of gestation in humans), critical neuronal populations, molecular adaptations in remaining neurons, etc. These models demonstrate again that perturbation in cortical development can reproduce some of the behavioral characteristics associated with schizophrenia, including those linked to dopamine systems.

\section{Testing the Relevance of Early Stressful Experience}

This group of models focuses on the long-lasting consequences of stress for brain development and for shaping adult behavioral responses. They have been variably used as models of depression, anxiety, and schizophrenia, diseases in which stress has long been thought to play some role. Stress has been postulated as a factor in so called "two hit" models of schizophrenia in which two independent insults (e.g., aberrant genetic trait and stressful experience) are thought to be necessary for the occurrence of the disorder. In rodents, early life exposure to experiential stressors such as maternal separation (Liu et al. 1997) and social isolation (Jones et al. 1992; Geyer et al. 1993; Wilkinson et al. 1994) produce numerous hormonal, neurochemical and behavioral changes, including locomotor hyperactivity in a novel environment, maze learning impairments, anxiety, latent inhibition and sensorimotor gating deficits. Of particular interest is that some of these alterations emerge in adult life and can be restored by a wide range of antipsychotics, including various typical and atypical drugs (Varty and Higgins 1995; Ellenbroek et al. 1998; Bakshi et al. 1998). Importantly, the effects of adverse early life events (e.g., maternal separation) on adult reactivity are strongly influenced by genetic as well as non-genomic factors (Zaharia et al. 1996; Anisman et al. 1998; Francis et al. 1999).

These models provide important evidence for an interaction between genetic predisposition and early life experiences and demonstrate that both are involved in 
shaping the adult stress response system and adult patterns of behavior. They might thus represent an interesting approach to study the interactions of these variables in schizophrenia.

\section{Neonatal Brain Lesions}

Another series of studies have focused on neonatal damage of restricted brain regions in rats (Lipska et al. 1993; Flores et al. 1996a; Chambers et al. 1996; Wan et al. 1996, 1998; Wan and Corbett 1997; Brake et al. 1999, Black et al. 1998; Becker et al. 1999; Grecksch et al. 1999; Schroeder et al. 1999) and in monkeys (Beauregard and Bachevalier 1996; Bertolino et al. 1997; Saunders et al. 1998; Bachevalier et al. 1999). The main objective of many of these studies is to disrupt development of the hippocampus, a brain area consistently implicated in human schizophrenia (Falkai and Bogerts 1986; Jeste and Lohr 1989; Bogerts et al. 1990; Suddath et al. 1990; Eastwood et al. 1995, 1997; Eastwood and Harrison 1995, 1998; Weinberger 1999), and thus disrupt development of the widespread cortical and subcortical circuitry in which the hippocampus participates. The lesions were intended to involve regions of the hippocampus that directly project to the prefrontal cortex, i.e., ventral hippocampus and ventral subiculum (Jay et al. 1989; Carr and Sesack 1996), and that correspond to the anterior hippocampus in humans, a region that shows anatomical abnormalities in schizophrenia (Suddath et al. 1990).

Neonatal excitotoxic lesions of the rat ventral hippocampus (VH) lead in adolescence or early adulthood to the emergence of abnormalities in a number of dopamine-related behaviors, which bear close resemblance to behaviors seen in animals sensitized to psychostimulants. When tested as juveniles (postnatal day 35), rats with the neonatal VH lesions are less social than controls (Sams-Dodd et al. 1997), but otherwise behave normally in motor tests involving exposure to stress and dopamine agonists. In adolescence and adulthood (postnatal day 56 and older), lesioned animals display markedly changed behaviors thought to be primarily linked to increased mesolimbic/nigrostriatal dopamine transmission (motor hyperresponsiveness to stress and stimulants, enhanced stereotypies). They also show enhanced sensitivity to glutamate antagonists (MK-801 and PCP), deficits in PPI and latent inhibition, impaired social behaviors and working memory problems (Lipska and Weinberger 1993, 1994a, 1994b; Lipska et al. 1995a; Becker et al. 1999; Grecksch et al. 1999; Al-Amin et al. in press; Hori et al. 1999), phenomena showing many parallels with schizophrenia.

Emergence of the behavioral changes in adolescence appears not to be related to the surge of gonadal hormones during puberty because a similar temporal pat- tern of abnormalities is observed in animals depleted of gonadal hormones prior to puberty (Lipska and Weinberger 1994b). Notably, removal of prefrontal neurons in adult animals with the earlier hippocampal lesion restores some of the behaviors (i.e., these modulated by but not critically dependent on the prefrontal cortex, such as hyperlocomotion after amphetamine), suggesting that aberrant development of the prefrontal cortex in the context of early damage to the hippocampus may be a critical factor in the onset of the syndrome (Lipska et al. 1998a). In this context, it is important to emphasize that anatomical findings from post mortem studies and neuropsychological and neuroimaging studies of brain function in patients with schizophrenia have implicated prefrontal cortical maldevelopment and a developmental "dysconnection" of the temporolimbic and prefrontal cortices (for review, see Weinberger 1995). Although the exact mechanisms of a seemingly similar "dysconnection" and malfunction of the prefrontal cortex in the VH lesioned rats need to be elucidated, preliminary findings from molecular and electrophysiological studies (such as reduced cortical levels of $\mathrm{N}$-acetylaspartate (NAA), attenuated stress-induced cortical dopamine release, attenuated cortical expression of a membrane glutamate transporter EAAC1 and of a synthetic enzyme for $\gamma$ aminobutyric acid (GABA), glutamate decarboxylase- 67 (GAD67), reduced BDNF expression, altered cortical expression of transcription factors, $c-f o s$ and $\Delta$ fosB, as well as altered firing pattern of cortical pyramidal neurons in response to ventral tegmental area (VTA) stimulation) suggest that aberrant cortical dopamine/glutamate/ GABA interactions may underlie cortical dysfunction in the neonatally VH lesioned rats (Lipska et al. 1995b; Bertolino et al. 1999; Lee et al. 1998; Ashe et al. 1999; O'Donnell et al. 1999). We have recently reported that excitotoxic prefrontal cortical lesions in adult animals cause downstream striatal NAA losses and reduced GAD-67 mRNA expression, and suggested that both changes might reflect transsynaptic pathology (Roffman et al. 2000). It is possible that similar transsynaptic events occur in response to the neonatal $\mathrm{VH}$ lesion but further work is required to determine if and by what mechanisms molecular changes in prefrontal neurons are linked. It is interesting to note that many of these changes have been reported in stress- and psychostimulant-sensitization models (Vanderschuren et al. 1999; Gambarana et al. 1999; Feldpausch et al. 1998), as well as in patients with schizophrenia (Akbarian et al. 1995; Bertolino et al. 1998). Subcortical function in the neonatally lesioned rats is also altered in a fashion consistent with at least some reports on behavioral sensitization (Imperato et al. 1996; Castner et al. 2000; Steiner and Gerfen 1998; Nestler and Aghajanian 1997), i.e., striatal dopamine release is attenuated in response to stress and amphetamine, midbrain expression of the membrane dopamine transporter (DAT) mRNA is reduced, striatal 
expression of dynorphin (an opioid peptide co-localized with D1 receptors) and of $\Delta$ fosB (a transcription factor sensitive to persistent stimulation) are enhanced (Lipska et al. 1998b; Lee et al. 1998). It should be noted, however, that enhanced rather than attenuated striatal dopamine release has been observed in other paradigms of sensitization to psychostimulants (for review, see Spanagel and Weiss 1999) as well as in a subgroup of schizophrenics as evidenced by recent SPECT studies (AbiDargham et al. 1998; Laruelle et al. 1996; Breier et al. 1997). Nevertheless, an array of behavioral and molecular changes associated with this model suggest that early developmental insult of the ventral hippocampus may facilitate sensitization of the dopamine system, and thereby account for the adult onset of a maladaptive condition characterized by a vriety of dopamine-related abnormalities. Similar pathophysiological mechanisms have been hypothesized to underlie schizophrenia (Lieberman et al. 1997; Meng et al. 1998; Duncan et al. 1999). Unlike psychostimulant sensitization models, however, the neonatal lesion model does not target the dopamine system directly and similar sensitization-like phenomena are not seen following an analogous hippocampal lesion in adult animals. It may be of considerable heuristic interest to determine how the developmental lesion initiates the subsequent behavioral and molecular phenomena associated with sensitization.

In terms of the predictive validity of the neonatal $\mathrm{VH}$ lesion model, antipsychotic drugs normalize some lesion-induced behaviors (Lipska and Weinberger 1994a; Sams-Dodd et al. 1997). Drugs targeting the glutamate system may also prove beneficial; LY293558, an AMPA antagonist, is highly efficient in blocking hyperlocomotion in the neonatally lesioned rats at doses that do not affect locomotor activity in controls (Al-Amin et al. in press). Thus, this model may have predictive validity and heuristic potential to identify drugs with new mechanisms of action. The model also appears to mimic a spectrum of neurobiological and behavioral features of schizophrenia, including functional pathology in presumably critical brain regions interconnected with the hippocampal formation and targeted by antipsychotic drugs - the striatum/nucleus accumbens and the prefrontal cortex (see Table 2). It is noteworthy that in the non-human primate, early postnatal damage of the hippocampal region also alters development of the dorsal prefrontal cortex and the mechanisms whereby the dorsal prefrontal cortex regulates subcortical dopamine function, phenomena similar to those described in patients with schizophrenia (Saunders et al. 1998; Bertolino et al. 1997, 2000). Thus, neonatal damage to the hippocampus of the rat appears to reproduce a broad spectrum of schizophrenia related phenomena, and establishes the neurobiological plausibility of early damage having a delayed impact on neural functions implicated in schizophrenia.
Developmental lesions of other brain structures implicated in schizophrenia and components of a limbicneocortical circuit (e.g., thalamus, prefrontal cortex) also have been considered as models. For instance, thalamic excitotoxic lesions in PD7 rats result in adult expression of apomorphine- and amphetamine-induced hyperlocomotion (Rajakumar et al. 1996). Intracerebroventricular infusions of kainic acid into neonatal (PD7) rats lead in adulthood to a reduction in neural numbers in the dorsal hippocampus, and are associated with changes in the expression of subpopulations of glutamate receptors and immediate early genes (Csernansky et al. 1998; Montgomery et al. 1999). Neonatal (PD7) excitotoxic damage of the medial prefrontal cortex was reported to produce delayed behavioral effects accompanied by dopamine receptor changes (Flores et al. 1996b), although others did not confirm these data (Lipska et al. 1998a). The spectrum of behavioral and cellular parameters examined in these models is rather limited at this time.

Another neonatal insult with intriguing implications is selective depletion of serotonin in neonatal rats (by tryptophan hydroxylase inhibitor parachlorophenylalanine, PCPA) that decreases markers of synaptic density in the adult brain, and results in cognitive deficits (Mazer et al. 1997). These effects are somewhat similar to those reported in the post mortem schizophrenic brain (Weinberger 1999), but other schizophrenia-relevant aspects need to be tested in this model.

Although developmental lesion models represent a rather crude technique to study the role of particular brain regions, transmitter systems or the connections between them, they have confirmed the plausibility of neurodevelopmental damage having selected deleterious effects after a prolonged period of relative normalcy. In this respect, they appear to have face validity not just in terms of behavioral, cellular and pharmacological phenomena, but also in terms of the temporal course of the clinical disorder. As models of developmental pathology, they certainly lack construct validity, as the schizophrenic brain does not manifest a "lesion" analogous to any of these models; but they may have heuristic value in discovering molecular consequences of early brain damage, and new treatment prospects.

\section{N-METHYL-D-ASPARTATE (NMDA) RECEPTOR BLOCKADE}

In addition to the non-pharmacological, non-dopaminergic approaches described above, pharmacological blockade of NMDA receptors in adult animals has gained popularity as a model of schizophrenia. Observations that noncompetitive NMDA antagonists, such as phencyclidine (PCP) and ketamine, exacerbate some psychotic symptoms in schizophrenic patients and 
have psychotomimetic effects in normal humans (Krystal et al. 1994; Lahti et al. 1995) have encouraged speculation that some aspects of schizophrenia may relate to abnormal glutamatergic function. This has been further supported by post mortem studies in schizophrenia showing a variety of changes in the glutamate system, including altered glutamate metabolism and expression of various glutamate receptors (Javitt and Zukin 1991; Akbarian et al. 1996; Jentsch and Roth 1999; Weinberger 1999).

In rodents and monkeys, acute sub-anesthetic doses of NMDA antagonists produce a constellation of phenomena potentially relevant to schizophrenic symptomatology, including hyperlocomotion, enhanced stereotyped behaviors, cognitive and sensorimotor gating deficits, and impaired social interactions. PCP as well as other NMDA antagonists acutely increase extracellular levels of dopamine and glutamate (as well as norepinephrine and acetylcholine) in the prefrontal cortex, and alter firing patterns of dopaminergic and nucleus accumbens neurons (Verma and Moghaddam 1996; O'Donnell and Grace 1998). Repeated administration of PCP can also induce robust behavioral and neurochemical changes even after long-term withdrawal (Jentsch et al. 1997, 1998a, 1998b). Of particular interest is differential dysregulation of the firing patterns of mesolimbic and mesocortical dopaminergic neurons by low, behaviorally relevant doses of NMDA antagonists. These changes in dopamine cell firing may render them unresponsive or inappropriately responsive to salient environmental stimuli such as stress and reward (Murase et al. 1993; Mathe et al. 1998). If a similar process underlies psychotic symptoms and cognitive deficits in schizophrenia, the NMDA antagonist model may offer novel treatment strategies targeting glutamate rather than dopamine. Recently, experimental approaches to reverse NMDA antagonist-induced abnormalities have included pharmacological enhancement of NMDA receptor activity, enhancement of metabotropic glutamate receptor (mGluR2) activity, and blockade of AMPA receptors (Moghaddam et al. 1997; Moghaddam and Adams 1998), the latter approach shown to be also effective in the neonatal hippocampal lesion model (see above). Thus, a model based on a primary glutamatergic abnormality appears to show important heuristic properties in terms of identifying potential novel therapies. This model may offer insight into molecular adaptations that follow chronic NMDA blockade, and identify new therapeutic targets. Notably, the repeated no-competitive NMDA blockade model, which had also been intensely investigated from the perspective of behavioral sensitization and its role in drug addiction and reward mechanisms (Wolf et al. 1993), shares certain behavioral and neurochemical similarities with the neonatal hippocampal lesion model, including cognitive deficits (in particular, in working memory tasks), reduced frontal dopamine transmission (Jentsch et al. 1997, 1998a) and reduced GABA activity as indicated by reduced levels of GAD67 (Qin et al. 1994; Yonezawa et al. 1998), and disrupted social behaviors and augmented locomotor responses to stress and amphetamine (Jentsch et al. 1998b). The similarities between the models may reflect a common disruption of cortical glutamate/GABA function which may converge toward a common underlying process of behavioral sensitization. Unlike the etiological or neonatal lesions models, the NMDA antagonist approach does not, however, address the developmental component of schizophrenia.

\section{GENETIC PREDISPOSITION}

Schizophrenia is a highly heritable disorder that probably involves multiple genes with small effects across large populations (Kendler et al. 1996). Elucidating the roles of the susceptibility genes for this clinically diverse and probably genetically heterogeneous disorder will require considerable effort and is unlikely to be fully resolved soon. Modern technologies, involving targeted gene deletions or gene transfer techniques that have revolutionized experimental medicine, may provide a new generation of animal models for schizophrenia that may help in this daunting task.

Some genetic models for neurological diseases are almost perfect in terms of construct validity because transgenic animals may be, in a sense, "humanized" by the introduction of human genes involved in the disease or the mutated animal homologues of such genes (Loring et al. 1996). However, transgenic models also illustrate that even a highly accurate model in terms of construct validity may fail the test of face validity in terms of a phenotype analogous to the disorder. For instance, the Duchenne's muscular dystrophy mdx mutation mouse model is hardly symptomatic (Erickson 1996), the PDAPP transgenic mouse model of Alzheimer's disease which overexpresses human amyloid precursor protein (Johnson-Wood et al. 1997), does not have an isomorphic behavioral phenotype, and the hypoxanthineguanine phosphoribosyl-transferase (HPRT) knock-out mouse has no recognizable phenotype analogous to Lesch-Nyhan Disease (Wu and Melton 1993). Behavioral phenotypes of these models are not isomorphic with the disease, because genetic mutation can have remarkably different phenotypes when placed on different genetic backgrounds. Despite phenotypic dissimilarity, however, such models are faithful in terms of certain cellular characteristics and can be very useful in illuminating molecular mechanisms leading to pathological changes and in discovering new treatments. This approach is, of course, possible only if the disease can be attributed to specific human genes, and thus seems to 
have limited application in studying schizophrenia or other psychiatric illnesses at the present time.

In an attempt to test the possibility of involvement of various neurotransmitter receptors relevant to schizophrenia (D1-D5 subtypes of dopamine receptors, adenosine $\mathrm{A} 2 \mathrm{~A}$ receptors, $\alpha 2$-adrenergic receptors and NMDA receptors) and to elucidate their functional roles, investigators have used genetically altered mice in which expression of these receptors was selectively and usually completely suppressed (Sibley 1999). Probably the most intriguing is a recent attempt at targeting the NR1 subunit of the NMDA receptor in a genetic mouse model (Mohn et al. 1999), despite lack of direct evidence that an NMDA receptor gene is abnormal in schizophrenia. Mutant mice expressing only $5 \%$ of essential NR1 receptors show increased spontaneous hyperlocomotion that attenuates after a single injection of haloperidol and clozapine, and deficits in social and sexual behaviors that respond to acute clozapine treatment. Although some of these behavioral changes suggest increased dopaminergic tone, dopamine release and turnover are not altered in these animals. However, somewhat contrary to the phenotype expected in a schizophrenia model, NR1 mutant mice do not exhibit enhanced responsiveness to the NMDA antagonists, MK-801 or PCP. Continued studies of these mice will provide more information about the consequences of dramatic congenital hypofunction of the glutamatergic system and will shed light on interactions of the glutamatergic system with other neurotransmitter systems, but the relevance of this model to schizophrenia is yet unclear. This example underscores a unique problem of modeling the schizophrenic phenotype in animals that even a genetic model cannot escape-lack of pathognomonic neurobiological markers and unequivocal validation criteria.

Another promising genetic strategy is identification of predisposing candidate genes by selecting rodent lines or strains for particular behavioral traits. Such candidate genes may then be used to identify homologous human genes potentially involved in the etiology of schizophrenia. For instance, studies in inbred mice strains with deficits in sensory inhibition have indicated that altered expression and function of the $\alpha 7$ nicotinic cholinergic receptor may be responsible for some auditory sensory gating deficits (Stevens et al. 1998). A defect in the so-called "P50 auditory-evoked response" is found in patients with schizophrenia and in their unaffected relatives (Freedman et al. 1987). This evoked potential defect (but not schizophrenia itself because many individuals showing P50 deficits are clinically unaffected) was subsequently linked to a chromosome 15 locus, near the site of the $\alpha 7$-nicotinic cholinergic receptor gene (Freedman et al. 1997). This linkage finding, which echoed data from the earlier mice experiments, suggested that a genetic defect in the $\alpha 7$-nicotinic cholinergic receptor might be a predisposing factor in schizophrenia. Sequencing of the $\alpha 7$-nicotinic cholinergic receptor gene in individuals with this phenotype is currently in progress. Another example involves animals bred for high susceptibility to apomorphine-induced stereotypic behaviors (APO-SUS rats). These animals, in contrast to apomorphine nonresponsive (APO-UNSUS) rats, demonstrate various behavioral (e.g., prepulse inhibition and latent inhibition deficits), biochemical (e.g., elevated levels of tyrosine hydroxylase mRNA in the substantia nigra and D2 receptor binding in the dorsal striatum), and immunological (e.g., reduced sensitivity for rheumatoid arthritis) features implicated in schizophrenia (Ellenbroek et al. 1995, 2000). Thus, such behavioral trait-selected animals may be used as models of schizophrenia-prone individuals and provide material for novel gene identification and for candidate gene analyses.

Another model has combined neurodevelopmental and genetic predisposition approaches. Fisher344 rats, a highly stress-responsive inbred strain, show particularly high susceptibility to the behavioral effects of neonatal hippocampal damage. Lewis rats, on the other hand, bred for low stress responsiveness, appear to be resistant to the behavioral consequences of identical lesions (Lipska and Weinberger 1995). This lesion-genetic model may be used for identification of candidate genes that mediate behavioral responses to a neonatal hippocampal insult, and that, by extension, might predispose to or modify the expression of schizophrenia. These studies are currently under way.

Because recent data suggest a significant role for neurodevelopmental processes in schizophrenia, another approach to genetic modeling of schizophrenia may focus on manipulating in animals genes that play a role in neurodevelopment, maintenance of cell-cell connections, and trophic factors (Weickert and Weinberger 1998) (see Table 3). For instance, in an attempt to alter genes involved in neural migration, neural cell adhesion molecule isoform 180 (NCAM-180) gene was deleted in mice. Mice with this selective gene deletion display a marked reduction in the levels of PSA-NCAM (polysialic acid rich NCAM), a molecule involved in neuronal regeneration and plasticity, which has also been reported as reduced in the hippocampus of patients with schizophrenia (Barbeau et al. 1995). N-CAM-180 depleted mice are characterized by abnormal migration of neurons within the subventricular zone, altered cytoarchitecture of multiple brain regions, including olfactory bulb, hippocampus and cerebellum, enlarged ventricles and changes in behavior (PPI deficits) (Tomasiewicz et al. 1993; Wood et al. 1998). Although some of these changes resemble abnormalities observed in schizophrenia, more thorough phenotypic characterization is needed.

Because the early hippocampal damage models have demonstrated the plausibility of developmental defects 
Table 3. Potential Animal Models Based on Genetic Manipulation of Cellular Phenotype

\begin{tabular}{|c|c|c|}
\hline $\begin{array}{l}\text { Molecular Changes in } \\
\text { Schizophrenia }\end{array}$ & Brain Region & $\begin{array}{l}\text { Molecular Targets for Genetic } \\
\text { Manipulations in Animals }\end{array}$ \\
\hline Trophic/ECM molecules $\downarrow$ & Cortex, Hippocampus & $\begin{array}{l}\text { BDNF, LAMP, PSA-NCAM, } \\
\text { Reelin }^{a}\end{array}$ \\
\hline Glutamate function $\downarrow$ & Cortex, Hippocampus & $\begin{array}{l}\text { GluR1-4, GluR5-7, NR1-2, } \\
\text { KA1-2, GCP II, EAAC1, } \\
\text { GLT1 } \\
\text { GLAST }^{b}\end{array}$ \\
\hline GABA function $\downarrow$ & Cortex, Hippocampus & GAD67, GABA $(A)^{c}$ \\
\hline Synaptic markers $\downarrow$ & Cortex, Hippocampus & $\begin{array}{l}\text { Synapsin, Synaptophysin, } \\
\text { SNAP-25, GAT1,3, } \\
\text { Complexin }^{d}\end{array}$ \\
\hline Other Cellular markers $\downarrow$ & Cortex, Hippocampus & GAP-43, $\mathrm{MAPs}^{e}$ \\
\hline
\end{tabular}

Abbreviations: BDNF, Brain derived neurotrophic factor; ECM, Extracellular matrix; EAAC1, Neuronal glutamate transporter; GABA(A), $\widetilde{\gamma}$; aminobutyric acid A receptors; GAP-43, Neuronal growth-associated protein; GAD-67, Glutamate decarboxylase-67; GAT1,3, GABA transporters; GCP II, Glutamate carboxypeptidase II; GLT1, GLAST, glial glutamate transporters; GluR1-4, Subunits of AMPA ( $\alpha$-amino-3-hydroxy-5-methyl-4-isoxazolepropionic acid) receptor; GluR5-7 and KA1-2, Subunits of kainate receptor; LAMP, Limbic system-associated membrane protein, MAP, Microtubule-associated protein; NR1-2, Subunits of NMDA (N-methyl-D-aspartate) receptor; PSA-NCAM, Polysialylated neural cell adhesion molecule; SNAP-25, Synaptosomal-associated protein of $25 \mathrm{kDa}$.

$\downarrow$ Decreased expression or compromised function.

Selected references:

${ }^{a}$ Vawter et al. 1998; Barbeau et al. 1995; Impagnatiello et al. 1998; Fatemi et al. 1999.

${ }^{b}$ Ohnuma et al. 1998; Eastwood et al. 1995, 1997.

${ }^{c}$ Benes et al. 1996, 1997; Huntsman et al. 1998; Dean et al. 1999.

${ }^{d}$ Eastwood and Harrison 1995; Glantz and Lewis 1997; Young et al. 1998; Harrison and Eastwood 1998; Karson et al. 1999.

ePerrone-Bizzozero et al. 1996; Eastwood and Harrison 1998.

in the hippocampus having a delayed impact on other neural circuits and systems (e.g., prefrontal cortex), transgenic models that selectively disrupt development of hippocampal circuitry may turn out to be especially heuristic. In a recent attempt to alter development of the hippocampus, the LIM homeobox Lhx5 gene, was deleted in mice. The Lhx5 homozygous mutant embryos showed dramatic defects in hippocampal morphology; however, most of the homozygotes died within a few days after birth. Somewhat less severe changes in hippocampal development, but still often lethal or too damaging to be considered relevant to schizophrenia, have been reported in mice with null deletions of other homeobox genes [e.g., Emx2 (Pellegrini et al. 1996) and Lhx2 (Porter et al. 1997)] as well as genes involved in neural migration during development [e.g., $\beta$ subunit of platelet-activating factor acetylhydrolase Pafah1b1 (or Lis1) (Hirotsune et al. 1998), cycline-dependent kinase 5 (Cdk5) (Ohshima et al. 1996), mdab1 (Sheldon et al. 1997) and reeler]. A more promising strategy might involve conditional reduction (or enhancement) of expression of certain genes restricted to critical periods in development, an approach that has recently been used in a drug addiction model that inducibly overexpresses $\Delta$ fosB (Kelz et al. 1999). Table 3 contains other suggestions for novel models based on transgenic approaches to reproduce specific cellular abnormalities that have been implicated in certain brain regions in schizophrenia; not all of these findings, however, have been independently replicated. Such developmental genetic models may provide new candidate genes for assessment in clinical studies and help to model the cell biology of this complex disorder. Candidate genes selected from their chromosomal position near genetic loci linked to schizophrenia might also be future targets for transgenic modes.

\section{CONCLUDING REMARKS}

The approach to studying the etiology and pathophysiology of schizophrenia at the level of animal neurobiology has become much more sophisticated. Schizophrenia had long been regarded as a social or psychological illness, not a brain disorder with a particular neurobiological cause. This situation is changing rapidly in light of mounting evidence linking schizophrenia to certain neuropathological processes in the brain, although their origin is still unclear. Heuristic animal models may prove to be important tools in testing new theories about the origin and mechanisms of this disorder. In particular, some of the recent models have confirmed the plausibility of neurodevelopmental insults having prolonged effects on the dopamine system and behaviors relevant to schizophrenia, and supported the notion that disruption of glutamatergic neurotransmission may lead to new approaches to treatment. The neonatal lesion model has suggested that the effects of an early ventral hippocampal insult, rather than being compensated for, precipitate a state remarkably similar to stress- or psychostimulant-induced sensitization, associated with long lasting maladaptive cellular changes 
that lead to delayed onset of abnormal behaviors. Mechanisms underlying sensitization to either stress, amphetamine, cocaine, opioids or non-competitive NMDA antagonists are not well understood and seem to involve complex changes in multiple neurotransmitter systems, including dopamine, glutamate and GABA. If the effects of sensitization following developmental abnormalities of the cortex are, indeed, involved in the adolescent/adult onset of schizophrenia-like changes in this model, and by extension in schizophrenia, this may underscore the importance of preventive treatment strategies directed at reducing the impact of experiential stressors in predisposed individuals. Findings from the neonatal stress models discussed above might provide clues about the mechanisms of such potential interventions.

Modern technologies that have been successfully applied to animal modeling of genetic neurological diseases may one day also open the door to our understanding of the mechanisms underlying psychiatric disorders. The transgenic murine models, in which mutations homologous to mutations in humans are inserted by transgenesis or by stem cell knockouts, may seem superior to any pharmacological, surgical or experiential models, but they have their own limitations. It is clear that most psychiatric disorders, including schizophrenia, are multifactorial, [i.e., multiple genes interact with multiple environmental factors to create a particular phenotype (Egan and Weinberger 1997)]. Theoretically at least, by choosing the right combination of the mutation and modifier genes as well as appropriate environmental influences on their expression, one might be able to create at the cellular level a high fidelity animal model of such a complex human disease as schizophrenia.

\section{REFERENCES}

Abi-Dargham A, Gil R, Krystal J, Baldwin RM, Seibyl JP, Bowers $M$, van Dyck CH, Charney DS, Innis RB, Laruelle M (1998): Increased striatal dopamine transmission in schizophrenia: Confirmation in a second cohort. Am J Psychiatry 155: 761-767

Adams W, Kendell, RE, Hare EH, Munk-Jorgensen,P (1993): Epidemiological evidence that maternal influenza contributes to the aetiology of schizophrenia: An analysis of Scottish, English and Danish data. Br J Psychiatry 163:169-177

Akbarian S, Bunney WE Jr, Potkin SG, Wigal SB, Hagman JO, Sandman CA, Jones EG (1993a): Altered distribution of nicotinamide-adenine dinucleotide phosphate-diaphorase cells in frontal lobe of schizophrenics implies disturbances of cortical development. Arch Gen Psychiatry 50:169-177

Akbarian S, Vinuela A, Kim JJ, Potkin SG. Bunney WE Jr, Jones EG (1993b): Distorted distribution of nicotina- mide-adenine dinucleotide phosphate-diaphorase neurons in temporal lobe of schizophrenics implies anomalous cortical development. Arch Gen Psychiatry 50:178-187

Akbarian S, Kim JJ, Potkin SG, Hagman JO, Tafazzoli A, Bunney WE Jr, Jones EG (1995): Gene expression for glutamic acid decarboxylase is reduced without loss of neurons in prefrontal cortex of schizophrenics. Arch Gen Psychiatry 52:258-266

Akbarian S, Sucher NJ, Bradley D, Tafazzoli A, Trinh D, Hetrick WP, Potkin SG, Sandman CA, Bunney WE Jr, Jones EG (1996): Selective alterations in gene expression for NMDA receptor subunits in prefrontal cortex of schizophrenics. J Neurosci 16:19-30

Al-Amin HA, Weinberger DR, Lipska BK (in press): Exaggerated MK-801-induced motor hyperactivity in rats with the neonatal lesion of the ventral hippocampus. Behav Pharm

Anisman H, Zaharia MD, Meaney MJ, Merali Z (1998): Do early-life events permanently alter behavioral and hormonal responses to stressors? Int J Dev Neurosci 16:149-164

Arnold SE, Hyman BT, van Hoesen GW, Damasio AR (1991): Some cytoarchitectural abnormalities of the entorhinal cortex in schizophrenia. Arch Gen Psychiatry 48:625-632

Ashe P, Chlan-Fourney J, Juorio AV, Li X-M, Boulton AA (1999): Brain-derived neurotrophic factor mRNA in rats with neonatal ibotenic acid lesions of the ventral hippocampus. Soc Neurosci Abstract 635.11

Bachevalier J, Alvarado MC, Malkova L (1999): Memory and socioemotional behavior in monkeys after hippocampal damage incurred in infancy or in adulthood. Biol Psychiatry 46(3):329-339

Bakshi VP, Swerdlow NR, Braff DL, Geyer MA (1998): Reversal of isolation rearing-induced deficits in prepulse inhibition by Seroquel and olanzapine. Biol Psychiatry 43:436-445

Barbeau D, Liang JJ, Robitalille Y, Quirion R, Srivastava LK (1995): Decreased expression of the embryonic form of the neural cell adhesion molecule in schizophrenic brains. Proc Natl Acad Sci USA 92:2785-2789

Beauregard M, Bachevalier J (1996): Neonatal insult to the hippocampal region and schizophrenia: A review and a putative animal model. Can J Psychiatry 41(7):446-456

Becker A, Grecksch G, Bernsteinn H-G, Hollt V, Bogerts B (1999): Social behavior in rats lesioned with ibotenic acid in the hippocampus: Quantitative and qualitative analysis. Psychopharmacology 144:333-338

Benes FM, McSparren J, Bird ED, San Giovanni JP, Vincent SL (1991): Deficits in small interneurons in prefrontal cortex and anterior cingulate cortices of schizophrenic and schizoaffective patients. Arch Gen Psychiatry 48:996-1001

Benes FM, Vincent SL, Alsterberg G, Bird ED, san Giovanni JP (1992): Increased GABA-A receptor binding in superficial laminae in cingulate cortex of schizophrenic brain. J Neurosci 12:924-929

Benes FM, Vincent SL, Marie A, Khan Y (1996): Up-regulation of GABA-A receptor binding on neurons of the prefrontal cortex in schizophrenic subjects. Neuroscience 7:1021-1031 
Benes FM, Wickramasinghe R, Vincent SL, Khan Y, Todtenkopf M (1997): Uncoupling of GABA(A) and benzodiazepine receptor binding activity in the hippocampal formation of schizophrenic brain. Brain Res 755:121-129

Bertolino A, Saunders RC, Mattay VS, Bachevalier J, Frank JA, Weinberger DR (1997): Altered development of prefrontal neurons in rhesus monkeys with neonatal mesial temporo-limbic lesions: A proton magnetic resonance spectroscopic imaging study. Cerebral Cortex 7:740-748

Bertolino A, Callicott JH, Elman I, Mattay VS, Tedeschi G, Frank JA, Breier A, Weinberger DR (1998): Regionally specific neuronal pathology in untreated patients with schizophrenia: A proton magnetic resonance spectroscopic imaging study. Biol Psychiatry 43:641-648

Bertolino A, Roffman JL, Lipska BK, Van Gelderen P, Olson A, Weinberger DR (1999): Postpubertal emergence of prefrontal neuronal deficits and altered dopaminergic behaviors in rats with neonatal hippocampal lesions. Soc Neurosci Abstract 520.8

Bertolino A, Breier A, Callicott JH, Adler C, Mattay VS, Shapiro M, Frank JA, Pickar D, Weinberger DR (2000): The relationship between dorsolateral prefrontal neuronal $\mathrm{N}$-acetylaspartate and evoked release of striatal dopamine in schizophrenia. Neuropsychopharmacology 22:125-132

Black MD, Lister S, Hitchcock JM, Giersbergen P, Sorensen SM (1998): Neonatal hippocampal lesion model of schizophrenia in rats: Sex differences and persistence of effects into maturity. Drug Dev Res 43:206-213

Black MD, Selk DE, Hitchcock JM, Wetttstein JG, Sorensen SM (1999): On the effect of neonatal nitric oxide synthase inhibition in rats: A potential neurodevelopmental model of schizophrenia. Neuropharmacology 38:1299-1306

Bloom FE (1993): Advancing a neurodevelopmental origin of schizophrenia. Arch Gen Psychiatry 50:224-227

Bogerts B, Ashtar M, Degreef G, Alvir JMJ, Bilder RM, Lieberman JA (1990): Reduced temporal limbic structure volumes on magnetic resonance images in first-episode schizophrenia. Psychiatr Res Neuroimaging 35:1-13

Braff DL, Geyer MA (1990): Sensorimotor gating and schizophrenia: Human and animal model studies. Arch Gen Psychiatry 47:181-188

Brake W, Noel MB, Boksa P, Gratton A (1997a): Influence of perinatal factors on the nucleus accumbens dopamine response to repeated stress during adulthood: An electrochemical study in rat. Neuroscience 77:1067-1076

Brake W, Boksa P, Gratton A (1997b): Effects of perinatal anoxia on the locomotor response to repeated amphetamine administration in adult rats. Psychopharmacology 133:389-395

Brake WG, Sullivan RM, Flores G, Srivastava L, Gratton A (1999): Neonatal ventral hippocampal lesions attenuate the nucleus accumbens dopamine response to stress: An electrochemical study in the rat. Brain Res 831:25-32

Breier A, Su TP, Saunders R, Carson RE, Kolachana BS, de Bartolomeis A, Weinberger DR, Weisenfeld N, Malhotra AK, Eckelman WC, Pickar D (1997): Schizophrenia is associated with elevated amphetamine-induced synaptic dopamine concentrations: Evidence from a novel positron emission tomography method. Proc Natl Acad Sci USA 94:2569-2574
Brown AS, Susser ES, Butler PD, Richardson AR, Kaufmann CA, Gorman JM (1996): Neurobiological plausibility of prenatal nutritional deprivation as a risk factor for schizophrenia. J Nerv Ment Dis 184:71-85

Carr DB, Sesack SR (1996): Hippocampal afferents to the rat prefrontal cortex: Synaptic targets and relation to dopaminergic terminals. J Comp Neurol 369:1-15

Castner SA, Al-Tikriti MS, Baldwin RM, Seibyl JP, Innis RB, Goldman-Rakic PS (2000): Behavioral changes and [123I]IBZM equilibrium SPECT measurement of amphetamine-induced dopamine release in rhesus monkeys exposed to subchronic amphetamine. Neuropsychopharmacology 22:4-13

Cintra L, Granados L, Aguilar A, Kemper T, DeBassio W, Galler J, Morgane P, Duran P, Diaz-Cintra S (1997): Effects of prenatal protein malnutrition on mossy fibers of the hippocampal formation in rats of four age groups. Hippocampus 7:184-191

Chambers RA, Moore J, McEvoy JP, Levin ED (1996): Cognitive effects of neonatal hippocampal lesions in a rat model of schizophrenia. Neuropsychopharmacology 15:587-594

Conrad AJ, Abebe T, Ron A, Forsythe S, Scheibel B (1991): Hippocampal pyramidal cell disarray in schizophrenia as a bilateral phenomenon. Arch Gen Psychiatry 48:413-417

Costall B, Naylor RJ (1995): Animal neuropharmacology and its prediction of clinical response. In Hirsch SR, Weinberger DR (eds), Schizophrenia. Oxford, Blackwell Science Ltd, pp. 401-424

Cotter D, Takei N, Farrell M, Sham P, Quinn P, Larkin C, Oxford J, Murray R, O'Callaghan E (1995): Does prenatal exposure to influenza in mice induce pyramidal cell disarray in the dorsal hippocampus? Schiz Res 16:233-241

Csernansky JG, Csernansky CA, Kogelman L, Montgomery EM, Bardgett ME (1998): Progressive neurodegeneration after intracerebroventricular kainic acid administration in rats: Implications for schizophrenia? Biol Psychiatry 44(11):1143-1150

Dalman C, Allebeck P, Cullberg J, Grunewald C, Koster M (1999): Obstetric complications and the risk of schizophrenia: A longitudinal study of a national birth cohort. Arch Gen Psychiatry 56:234-240

Dean B, Hussain T, Hayes W, Scarr E, Kitsoulis S, Hill C, Opeskin K, Copolov DL (1999): Changes in serotonin2A and $\operatorname{GABA}(\mathrm{A})$ receptors in schizophrenia: Studies on the human dorsolateral prefrontal cortex. J Neurochem 72:1593-1599

DeLisi LE, Dauphinais ID, Gershon ES (1988): Perinatal complications and reduced size of brain limbic structures in afmilial schizophrenia. Schizophr Bull 14:185-191

Duncan GE, Sheitman BB, Lieberman JA (1999): An integrated view of pathophysiological models of schizophrenia. Brain Res Brain Res Rev 29:250-264

Ellenbroek BA, Cools AR (1990): Animal models with construct validity for schizophrenia. Behav Pharm 1:469490

Ellenbroek BA, Geyer MA, Cools AR (1995): The behavior of APO-SUS rats in animal models with construct validity for schizophrenia. J Neurosci 11:7604-7611 
Ellenbroek BA, van den Kroonenberg PT, Cools AR (1998): The effects of an early stressful life event on sensorimotor gating in adult rats. Schizophr Res 30(3):251-260

Ellenbroek BA, Sluyter F, Cools AR (2000): The role of genetic and early environmental factors in determining apomorphine susceptibility. Psychopharmacology 148: 124-131

Eastwood SL, Harrison PJ (1995): Decreased synaptophysin in the medial temporal lobe in schizophrenia demonstrated using immunoautoradiography. Neuroscience 69:339-343

Eastwood SL, Burnet PW, Harrison PJ (1997): GluR2 glutamate receptor subunit flip and flop isoforms are decreased in the hippocampal formation in schizophrenia: A reverse transcriptase-polymerase chain reaction (RT-PCR) study. Brain Res Mol Brain Res 44:92-98

Eastwood SL, McDonald B, Burnet PW, Beckwith JP, Kerwin RW, Harrison PJ (1995): Decreased expression of mRNAs encoding non-NMDA glutamate receptors GluR1 and GluR2 in medial temporal lobe neurons in schizophrenia. Brain Res Mol Brain Res 29:211-223

Eastwood SL, Harrison PJ (1998): Hippocampal and cortical growth-associated protein-43 messenger RNA in schizophrenia. Neuroscience 86:437-448

Egan M, Weinberger DR (1997): Neurobiology of schizophrenia. Curr Op Neurobiol 7:701-707

El-Khodor BF, Boksa P (1997): Long-term reciprocal changes in dopamine levels in prefrontal cortex versus nucleus accumbens in rats born by Cesarean section compared to vaginal birth. Exp Neurol 145:118-129

El-Khodor BF, Boksa P (1998): Birth insult increases amphetamine induced responses in the adult rat. Neuroscience 87:893-904

Erickson RP (1996): Mouse models of human genetic disease: Which mouse is more like a man? Bioessays 18:993-998

Falkai P, Bogerts B (1986): Cell loss in the hippocampus of schizophrenics. Eur Arch Psychiatry Neurol Sci 236:154-161

Fatemi SH, Emamian ES, Kist D, Sidwell RW, Nakajima K, Akhter P, Shier A, Sheikh S, Bailey K (1999): Defective corticogenesis and reduction in Reelin immunoreactivity in cortex and hippocampus of prenatally infected neonatal mice. Mol Psychiatry 4:145-154

Feldpausch DL, Needham LM, Stone MP, Althaus JS, Yamamoto BK, Svensson KA, Merchant KM (1998): The role of dopamine D4 receptor in the induction of behavioral sensitization to amphetamine and accompanying biochemical and molecular adaptations. J Pharmacol Exp Ther 286:497-508

Flores G, Barbeau D, Quirion R, Srivastava LK (1996a): Decreased binding of dopamine D3 receptors in limbic subregions after neonatal bilateral lesion of rat hippocampus. J Neurosci 16:2020-2026

Flores G, Wood GK, Liang J-J, Quirion R, Srivastava LK (1996b): Enhanced amphetamine sensitivity and increased expression of dopamine D2 receptors in postpubertal rats after neonatal excitotoxic lesions of the medial prefrontal cortex. J Neurosci 16:7366-7375

Francis D, Diorio J, Liu D, Meaney MJ (1999): Nongenomic transmission across generations of maternal behavior and stress responses in the rat. Science 286(5442):1155-1158
Freedman R, Adler LE, Gerhardt GA, Waldo M, Baker N, Rose GM, Drebing C, Nagamoto H, Bickford-Weimer P, Franks R (1987): Neurobiological studies of sensory gating in schizophrenia. Schizophr Bull 13:669-678

Freedman R, Coon H, Myles-Worsley M, Orr-Urtreger A, Olincy A, Davis A, Polymeropoulos M, Holik J, Hopkins J, Hoff M, Rosenthal J, Waldo MC, Reimherr F, Wender P, Yaw J, Young DA, Breese CR, Adams C, Patterson D, Adler LE, Kruglyak L, Leonard S, Byerley W (1997): Linkage of a neurophysiological deficit in schizophrenia to a chromosome 15 locus. Proc Natl Acad Sci 94:587-592

Gambarana C, Masi F, Tagliamonte A, Scheggi S, Ghiglieri O, De Montis MG (1999): A chronic stress that impairs reactivity in rats also decreases dopaminergic transmission in the nucleus accumbens: A microdialysis study. J Neurochem 72(5):2039-2046

Geyer MA, Wilkinson LS, Humby T, Robbins TW (1993): Isolation rearing of rats produces a deficit in prepulse inhibition of acoustic startle similar to that in schizophrenia. Biol Psychiatry 34:361-372

Glantz LA, Lewis DA (1997): Reduction of synaptophysin immunoreactivity in the prefrontal cortex of subjects with schizophrenia. Regional and diagnostic specificity. Arch Gen Psychiatry 54:943-952

Grecksch G, Bernstein HG, Becker A, Hollt V, Bogerts B (1999): Disruption of latent inhibition in rats with postnatal hippocampal lesions. Neuropsychopharmacology 20:525-532

Harrison PJ, Eastwood SL (1998): Preferential involvement of excitatory neurons in medial temporal lobe in schizophrenia. Lancet 352:1669-1673

Hirotsune S, Fleck MW, Gambello MJ, Bix GJ, Chen A, Clark GD, Ledbetter DH, McBain CJ, Wynshaw-Boris (1998): Graded reduction of Pafah1b1 (Lis1) activity results in neuronal migration defects and early embryonic lethality. Nature Genet 19:333-339

Hori T, Subramaniam S, Carli M, Srivastava LK, Quirion R (1999): Effects of repeated phencyclidine administration on locomotor activity and forced swimming test in rats with neonatal ventral hippocampal lesions. Soc Neurosci Abstract 635.8

Hornig M, Weissenbock H, Horscroft N, Lipkin WI (1999): An infection-based model of neurodevelopmental damage. Proc Natl Acad Sci USA 96:12102-12107

Hultman CM, Ohman A, Cnattingius S, Wieselgren IM, Lindstrom LH (1997): Prenatal and neonatal risk factors for schizophrenia. Br J Psychiatry 170:128-133

Huntsman MM, Tran BV, Potkin SG, Bunney WE Jr, Jones EG (1998): Altered ratios of alternatively spliced long and short gamma2 subunit mRNAs of the gammaamino butyrate type A receptor in prefrontal cortex of schizophrenics. Proc Natl Acad Sci USA 95:15066-15071

Impagnatiello F, Guidotti AR, Pesold C, Dwivedi Y, Caruncho H, Pisu MG, Uzunov DP, Smalheiser NR, Davis JM, Pandey GN, Pappas GD, Tueting P, Sharma RP, Costa E (1998): A decrease of reelin expression as a putative vulnerability factor in schizophrenia. Proc Natl Acad Sci USA 95:15718-15723

Imperato A, Obinu MC, Carta G, Mascia MS, Casu MA, Gessa GL (1996): Reduction of dopamine release and 
synthesis by repeated amphetamine treatment: Role in behavioral sensitization. Eur J Pharmacol 317:231-237

Javitt DC, Zukin SR (1991): Recent advances in the phencyclidine model of schizophrenia. Am J Psychiatry 148:1301-1308

Jay TM, Glowinski J, Thierry A-M (1989): Selectivity of the hippocampal projection to the prelimbic area of the prefrontal cortex in the rat. Brain Res 505:337-340

Jentsch JD, Tran A, Le D, Joungren KD, Roth RH (1997): Subchronic phencyclidine administration reduces mesoprefrontal dopamine utilization and impairs prefrontal cortical-dependent cognition inn the rat. Neuropsychopharmacology 17:92-99

Jentsch JD, Redmond DE, Elsworth JD, Taylor JR, Youngren KD, Roth RH (1998a): Enduring cognitive deficits and cortical dopamine dysfunction in monkeys after longterm administration of phencyclidine. Science 277:953955

Jentsch JD, Taylor JR, Roth RH (1998b): Subchronic phencyclidine administration increases mesolimbic dopaminergic system responsivity and augments stress- and psychostimulant-induced hyperlocomotion. Neuropsychopharmacology 19(2):105-113

Jentsch JD, Roth RH (1999): The neuropsychopharmacology of phencyclidine: From NMDA receptor hypofunction to the dopamine hypothesis of schizophrenia. Neuropsychopharmacology 20:201-225

Jeste DV, Lohr JB (1989): Hippocampal pathologic findings in schizophrenia: A morphometric study. Arch Gen Psychiatry 46:1019-1024

Johnson-Wood K, Lee M, Motter R, Hu K, Gordon G, Barbour R, Khan K, Gordon M, Tan H, Games D, Lieberburg I, Schenk D, Seubert P, MacConlogue L (1997): Amyloid precursor protein processing and Abeta42 deposition in a transgenic mouse model of Alzheimer disease. Proc Natl Acad Sci USA 94:1550-1555

Johnston MV, Barks J, Greenmyre T, Silverstein F (1988): Use of toxins to disrupt neurotransmitter circuitry in the developing brain. Prog Brain Res 73:425-446

Jones GH, Hernandez TD, Kendall DA, Marsden CA, Robbins TW (1992): Dopaminergic and serotonergic function following isolation rearing in rats: Study of behavioral responses and postmortem and in vivo neurochemistry. Pharm Biochem Behav 43:17-35

Karson CN, Mrak RE, Schluterman KO, Sturner WQ, Sheng JG, Griffin WS (1999): Alterations in synaptic proteins and their encoding mRNAs in prefrontal cortex in schizophrenia: a possible neurochemical basis for "hypofrontality." Mol Psychiatry 4:39-45

Kelz MB, Chen J, Carlezon WA Jr, Whisler K, Gilden L, Beckmann AM, Steffen C, Zhang YJ, Marotti L, Self DW, Tkatch T, Baranauskas G, Surmeier DJ, Neve RL, Duman RS, Picciotto MR, Nestler EJ (1999): Expression of the transcription factor deltaFosB in the brain controls sensitivity to cocaine. Nature 401:272-276

Kendell RE, Kemp IW (1989): Maternal influenza in the etiology of schizophrenia. Arch Gen Psychiatry 46:878-882

Kendler KS, MacLean CJ, O’Neill FA, Burke J, Murphy B, Duke F, Shinkwin R, Easter SM, Webb BT, Zhang J, Walsh D, Straub RE (1996): Evidence for a schizophrenia vulnerability locus on chromosome $8 p$ in the Irish study of high-density schizophrenia families. Am J Psychiatry 153:1534-1540

Kirkpatrick B, Conley RC, Kakoyannis A, Reep RL, Roberts RC (1999): Interstitial cells of the white matter in the inferior parietal cortex in schizophrenia: An unbiased cell-counting study. Synapse 34:95-102

Kobayashi K, Forte TM, Taniguchi S, Ishida BY, Oka K, Chan $\mathrm{L}$ (2000): The $\mathrm{db} / \mathrm{db}$ mouse, a model for diabetic dyslipidemia: Molecular characterization and effects of Western diet feeding. Metabolism 49:22-31

Kornetsky C, Markowitz R (1978): Animal models of schizophrenia. In Lipton MA, DiMascio A, Killam KF (eds), Psychopharmacology: A Generation of Progress. New York, Raven Press, pp 583-593

Krystal JH, Karper LP, Seibyl JP, Freeman GK, Delaney R, Bremner JD, Heninger GR, Bowers MB Jr, Charney DS (1994): Subanesthetic effects of the noncompetitive NMDA antagonist, ketamine, in humans. Psychotomimetic, perceptual, cognitive, and neuroendocrine responses. Arch Gen Psychiatry 199-214

Lahti AC, Koffel B, LaPorte D, Tamminga CA (1995): Subanesthetic doses of ketamine stimulate psychosis in schizophrenia. Neuropsychopharmacology 13:9-19

Laruelle M, Abi-Dargham A, van Dyck CH, Gil R, D'Souza CD, Erdos J, McCance E, Rosenblatt W, Fingado C, Zoghbi SS, Baldwin RM, Seibyl JP, Krystal JH, Charney DS, Innis RB (1996): Single photon emission computerized tomography imaging of amphetamine-induced dopamine release in drug-free schizophrenic subjects. Proc Natl Acad Sci USA 93: 9235-9240

Lee CJ, Binder T, Lipska BK, Zhu Y, Weinberger DR, Nakabeppu Y, Robertson GS (1998): Neonatal ventral hippocampal lesions produce an elevation of $\Delta$-FosB-like protein(s) in the rodent neocortex. Soc Neurosci Abstract 24: 489

Lewis P, Patel A, Balazs R (1979): Effect of undernutrition on cell generation in the adult rat brain. Brain Res 168:186189

Lieberman JA, Sheitman BB, Kinon BJ (1997): Neurochemical sensitization in the pathophysiology of schizophrenia: Deficits and dysfunction in neuronal regulation and plasticity. Neuropsychopharmacology 17(4):205-229

Lillrank SM, Lipska BK, Weinberger DR (1995): Neurodevelopmental animal models of schizophrenia. Clin Neurosci 3:98-104

Lipska BK, Jaskiw GE, Weinberger DR (1993): Postpubertal emergence of hyperresponsiveness to stress and to amphetamine after neonatal hippocampal damage: A potential animal model of schizophrenia. Neuropsychopharmacology 9:67-75

Lipska BK, Weinberger DR (1993): Delayed effects of neonatal hippocampal damage on haloperidol-induced catalepsy and apomorphine-induced stereotypic behaviors in the rat. Dev Brain Res 75:213-222

Lipska BK, Weinberger DR (1994a): Subchronic treatment with haloperidol or clozapine in rats with neonatal excitotoxic hippocampal damage. Neuropsychopharmacology 10:199-205

Lipska BK, Weinberger DR (1994b): Gonadectomy does not 
prevent novelty- or drug-induced hyperresponsiveness in rats with neonatal excitototxic hippocampal damage. Dev Brain Res 78:253-258

Lipska BK, Swerdlow NR, Geyer MA, Jaskiw GE, Braff DL, Weinberger DR (1995a): Neonatal excitotoxic hippocampal damage in rats causes postpubertal changes in prepulse inhibition of startle and its disruption by apomorphine. Psychopharmacology 122:35-43

Lipska BK, Chrapusta SJ, Egan MF, Weinberger DR (1995b): Neonatal excitotoxic ventral hippocampal damage alters dopamine response to mild chronic stress and haloperidol treatment. Synapse 20:125-130

Lipska BK, Weinberger DR (1995): Genetic variation in vulnerability to the behavioral effects of neonatal hippocampal damage in rats. Proc Natl Acad Sci USA 92:8906-8910

Lipska BK, Al-Amin HA, Weinberger DR (1998a): Excitotoxic lesions of the rat medial prefrontal cortex: effects on abnormal behaviors associated with neonatal hippocampal damage. Neuropsychopharmacology 19:451464

Lipska BK, Khaing ZZ, Lerman DN, Weinberger DR (1998b): Neonatal damage of the rat ventral hippocampus reduces expression of a dopamine transporter. Soc Neurosci Abstract 24:365

Liu D, Diorio J, Tannenbaum B, Caldji C, Francis D, Freedman A, Sharma S, Pearson D, Plotsky PM, Meaney MJ (1997): Maternal care, hippocampal glucocorticoid receptors, and hypothalamic- pituitary-adrenal responses to stress. Science 277:1659-1662

Lohr JB, Bracha S (1989): Can schizophrenia be related to prenatal exposure to alcohol? Some speculations. Schizophr Bull 15:595-603

Loring JF, Paszty C, Rose A, McIntosh TK, Murai H, Pierce JES, Schramm SE, Wymore K, Lee VM-Y, Trojanowski JQ, Peterson KR (1996): Rational design of an animal model for Alzheimer's disease: Introduction of multiple human genomic transgenes to reproduce AD pathology in a rodent. Neurobiol Aging 17:173-182

Mathe JM, Nomikos GG, Schilstrom B, Svensson TH (1998): Non-NMDA excitatory amino acid receptors in the ventral tegmental area mediate systemic dizocilpine (MK801 ) induced hyperlocomotion and dopamine release in the nucleus accumbens. J Neurosci Res 51:583-592

Mazer C, Muneyyirci J, Taheny K, Raio N, Borella A, Whitaker-Azmitia P (1997): Serotonin depletion during synaptogenesis leads to decreased synaptic density and learning deficits I the adult rat: A possible model of neurodevelopmental disorders with cognitive deficits. Brain Res 760:68-73

McKinney WT, Moran EC (1981): Animal models of schizophrenia. Am J Psychiatry 138:478-483

McNiel TF (1988): Obstetric factors and perinatal injuries. In Tsuang MT, Simpson JC (eds), Handbook of Schizophrenia, Vol. 3., Nosology, Epidemiology and Genetic. Amsterdam, Elsevier, pp 319-344

Mednick SA, Machon RA, Huttunen MO, Bonett D (1988): Adult schizophrenia following prenatal exposure to influenza epidemic. Arch Gen Psychiatry 45:189-192

Meng ZH, Feldpaush DL, Merchant KM (1998): Clozapine and haloperidol block the induction of behavioral sensi- tization to amphetamine and associated genomic responses in rats. Brain Res Mol Brain Res 61(1-2):39-50

Mintz M, Youval G, Gigi A, Myslobodsky MS (1997): Rats exposed to prenatal gamma-radiation at day 15 of gestation exhibit enhanced persevaration in T-maze. Soc Neurosci Abstract 23:1365

Moghaddam B, Adams B, Verma A, Daly D (1997): Activation of glutamatergic neurotransmission by ketamine: A novel step in pathway from NMDA receptor blockade to dopaminergic and cognitive disruptions associated with the prefrontal cortex. J Neurosci 17:2921-2927

Moghaddam B, Adams B (1998): Reversal of phencyclidine effects by group II metabotropic glutamate receptor agonist in rats. Science 281:1349-1352

Mohn AR, Gainetdinov RR, Caron MG, Koller BH (1999): Mice with reduced NMDA receptor expression display behaviors related to schizophrenia. Cell 98:427-436

Montgomery EM, Bardgett ME, Lall B, Csernansky CA, Csernansky JG (1999): Delayed neuronal loss after administration of intracerebroventricular kainic acid to preweanling rats. Brain Res Dev Brain Res 112(1):107116

Morgane PJ, Austin-LaFrance R, Bronzino J, Tonkiss J, DiazCintra S, Cintra L, Kemper T, Galler JR (1993): Prenatal malnutrition and development of the brain. Neurosci Biobehav Rev 17:91-128

Moore H, Ghajarnia M, Grace AA (1998): Anatomy and function of prefrontal and limbic corticostriatal circuits in a rodent model of schizophrenia. 37th ACNP Annual Meeting Abstract 37:179

Murase S, Mathe JM, Grenhoff J, Svensson TH (1993): Effects of dizocilpine (MK-801) on rat midbrain dopamine cell activity: differential actions on firing pattern related to anatomical localization. J Neur Transm [Gen Sect] 91:13-25

Murray RM, Lewis SW (1987): Is schizophrenia a neurodevelopmental disorder? Br Med J 295:681-682

Nestler EJ, Aghajanian GK (1997): Molecular and cellular basis of addiction. Science 278:58-63

O'Callaghan E, Sham P, Takei N, Glover G, Murray RM (1991): Schizophrenia after prenatal exposure to 1957 A2 influenza epidemic. Lancet 337:1248-1250

O'Donnell P, Grace AA (1998): Phencyclidine interferes with the hippocampal gating of nucleus accumbens neuronal activity in vivo. Neuroscience 87:823-830

O'Donnell P, Lewis BL, Lerman D, Weinberger DR, Lipska BK (1999): Effects of neonatal hippocampal lesions on prefrontal cortical pyramidal cell responses to VTA stimulation. Soc Neurosci Abstract 664.2

Ohnuma T, Augood SJ, Arai H, McKenna PJ, Emson PC (1998): Expression of the human excitatory amino acid transporter 2 and metabotropic glutamate receptors 3 and 5 in the prefrontal cortex from normal individuals and patients with schizophrenia. Brain Res Mol Brain Res 56:207-217

Ohshima T, Ward JM, Huh CG, Longenecker G, Veeranna, Pant HC, Brady RO, Martin LJ, Kulkarni AB (1996): Targeted disruption of the cyclin-dependent kinase 5 gene results in abnormal corticogenesis, neuronal pathology and perinatal death. Proc Natl Acad Sci USA 93:11173-11178 
Olney JW, Farber NB (1995): Glutamate receptor dysfunction and schizophrenia. Arch Gen Psychiatry 52:9981007

Patel VB, Richardson PJ, Preedy VR (2000): Non-cardiac nucleic acid composition and protein synthesis rates in hypertension: studies on the spontaneously hypertensive rat (SHR) model. Clin Chim Acta 293:167-179

Pearce BD, Steffensen SC, Paoletti AD, Henriksen SJ, Buchmeier MJ (1996): Persistent dentate granule cell hyperexcitability following neonatal infection with lymphocytic choriomeningitis virus. J Neurosci 16:220-228

Pearce BD, Po CL, Pisell TL, Miller AH (1999): Lymphocytic responses and the gradual hippocampal neuron loss following infection with lymphocytic choriomeningitis virus (LCMV). J Neuroimmunol 101(2):137-147

Pellegrini M, Mansouri A, Simeone A, Boncinelli E, Gruss P (1996): Dentate gyrus formation requires Emx2. Development 122:3893-3898

Perrone-Bizzozero NI, Sower AC, Bird ED, Benowitz LI, Ivins KJ, Neve RL (1996): Levels of the growth-associated protein GAP-43 are selectively increased in association cortices in schizophrenia. Proc Natl Acad Sci USA 93:14182-14187

Porter FD, Drago J, Xu Y, Cheema SS, Wassif C, Huang SP, Lee E, Grinberg A, Massalas JS, Bodine D, Alt F, Westphal H (1997): Lhx2, a LIM homeobox gene, is required for eye, forebrain, and definitive erythrocyte development. Development 124:2935-2944

Qin ZH, Zhang SP, Weiss B (1994): Dopaminergic and glutamatergic blocking drugs differentially regulate glutamic acid decarboxylase mRNA in mouse brain. Brain Res Mol Brain Res 21(3-4):293-302

Rajakumar N, Williamson PC, Stoessl JA, Flumerfelt BA (1996): Neurodevelopmental pathogenesis of schizophrenia. Soc Neurosci Abstract 22:1187

Rakic P (1996): Experimental deletion of specific cortical neurons: Relevance to schizophrenia. 35th ACNP Annual Meeting Abstract 35:91

Roffman JL, Lipska BK, Bertolino A, Van Gelderen P, Olson AW, Khaing ZZ, Weinberger DR (2000): Local and downstream effects of excitotoxic lesions in the rat medial prefrontal cortex on in vivo ${ }^{1} \mathrm{H}-\mathrm{MRS}$ signals. Neuropsychopharmacology 22:430-439

Rott R, Herzog S, Fleischer B, Winokur A, Amsterdam J, Dyson W, Koprowski H (1985): Detection of serum antibodies to Borna disease virus in patients with psychiatric disorders. Science 228:755-756

Rupniak NMJ, Iversen, SD (1993): Cognitive impairment in schizophrenia: how experimental models using nonhuman primates may assist improved drug therapy for negative symptoms. Neuropsychologia 31:1133-1146

Sams-Dodd F, Lipska BK, Weinberger DR (1997): Neonatal lesions of the rat ventral hippocampus result in hyperlocomotion and deficits in social behaviour in adulthood. Psychopharmacology 132:303-310

Saunders RC, Kolachana BS, Bachevalier J, Weinberger DR (1998): Neonatal lesions of the temporal lobe disrupt prefrontal cortical regulation of striatal dopamine. Nature 393:169-171

Scheibel AB, Kovelman JA (1981): Disorientation of the hip- pocampal pyramidal cell and its processes in the schizophrenic patient. Biol Psychiatry 16:101-102

Schroeder H, Grecksch G, Becker A, Bogerts B, Höllt V (1999): Alterations of the dopaminergic and glutamatergic neurotransmission in adult rats with postnatal ibotenic acid hippocampal lesion. Psychopharmacology 145:61-66

Sheldon M, Rice DS, D'Arcangelo G, Yoneshima H, Nakajima K, Mikoshiba K, Howell BW, Cooper JA, Goldowitz D, Curran T (1997): Scrambler and yotari disrupt the disabled gene and produce a reeler-like phenotype in mice. Nature 389:730-733

Sibley DR (1999): New insights into dopaminergic receptor function using antisense and genetically altered animals. Annu Rev Pharmacol Toxicol 39:313-341

Solbrig MV, Koob GF, Fallon JH, Lipkin WI (1994): Tardive dyskinetic syndrome in rats infected with Borna disease virus. Neurobiol Disease 1:111-119

Solbrig MV, Koob GF, Joyce JN, Lipkin WI (1996a): A neural substrate of hyperactivity in Borna disease: changes in brain dopamine receptors. Virology 222:332-338

Solbrig MV, Koob GF, Fallon JH, Reid S, Lipkin WI (1996b): Prefrontal cortex dysfunction in Borna disease virus (BDV)-infected rats. Biol Psychiatry 40:629-636

Spanagel R, Weiss F (1999): The dopamine hypothesis of reward: Past and current status. Trends Neurosci 22:521-527

Suddath RL, Christisin GW, Torrey EF, Casanova M, Weinberger DR (1990): Anatomical abnormalities in the brains of monozygotic twins discordant for schizophrenia. N Engl J Med 322:789-794

Susser ES, Lin SP (1992): Schizophrenia after prenatal exposure to the Dutch Hunger Winter of 1944-1945. Arch Gen Psychiatry 49:983-988

Steiner H, Gerfen CR (1998): Role of dynorphin and enkephalin in the regulation of striatal output pathways and behavior. Exp Brain Res 123:60-76

Stevens KE, Kem WR, Mahnir VM, Freedman R (1998): Selective $\alpha 7$-nicotinic agonists normalize inhibition of auditory response in DBA mice. Psychopharmacology 136:320-327

Talamini LM, Koch T, Ter Horst GJ, Korf J (1998): Methylazoxymethanol acetate-induced abnormalities in the entorhinal cortex of the rat; parallels with morphological findings in schizophrenia. Brain Res 789:293-306

Tomasiewicz H, Ono K, Yee D, Thompson C, Goridis C, Rutishauser U, Magnuson T (1993): Genetic deletion of a neural cell adhesion molecule variant (N-CAM-180) produces distinct defects in the central nervous system. Neuron 11:1163-1174

Tonkiss J, Galler JR (1990): Prenatal protein malnutrition and working memory performance in adult rats. Behav Brain Res 40:95-107

Vanderschuren LJ, Schmidt ED, De Vries TJ, Van Moorsel CA, Tilders FJ, Schoffelmeer AN (1999): A single exposure to amphetamine is sufficient to induce long-term behavioral, neuroendocrine, and neurochemical sensitization in rats. J Neurosci 19:9579-9586

Varty GB, Higgins GA (1995): Examination of drug-induced and isolation-induced disruptions of prepulse inhibi- 
tion as models to screen antipsychotic drugs. Psychopharmacology 122:15-26

Vawter MP, Hemperly JJ, Hyde TM, Bachus SE, VanderPutten DM, Howard AL, Cannon-Spoor HE, McCoy MT, Webster MJ, Kleinman JE, Freed WJ (1998): VASE-containing N-CAM isoforms are increased in the hippocampus in bipolar disorder but not schizophrenia. Exp Neurol 154:1-11

Verma A, Moghaddam B (1996): NMDA receptor antagonists impair prefrontal cortex function as assessed via spatial delayed alternation performance in rats: Modulation by dopamine. J Neurosci 16:373-379

Waltrip RW, Buchanan RW, Summerfeld A, Breier A, Carpenter WT, Jr, Bryant NL, Rubin SA, Carbone KM (1995): Borna disease virus and schizophrenia. Psychiatr Res 56:33-44

Wan R-Q, Giovanni A, Kafka SH, Corbett R (1996): Neonatal hippocampal lesions induced hyperresponsiveness to amphetamine: Behavioral and in vivo microdialysis studies. Behav Brain Res 78:211-223

Wan RQ, Corbett R (1997): Enhancement of postsynaptic sensitivity to dopaminergic agonists induced by neonatal hippocampal lesions. Neuropsychopharmacology $16: 259-268$

Wan RQ, Hartman H, Corbett R (1998): Alteration of dopamine metabolites in CSF and behavioral impairments induced by neonatal hippocampal lesions. Physiol Behav 65:429-436

Weickert CS, Weinberger DR (1998): A candidate molecule approach to defining developmental pathology in schizophrenia. Schizophr Bull 24:303-316

Weinberger DR (1986): The pathogenesis of schizophrenia: a neurodevelopmental theory. In Nasrallah HA, Weinberger DR (eds), The Neurology of Schizophrenia. Amsterdam, Elsevier, pp 397-406.

Weinberger DR (1987): Implications of normal brain development for the pathogenesis of schizophrenia. Archiv Gen Psychiatry 44:660-669
Weinberger DR (1995): Schizophrenia as a neurodevelopmental disorder. In Hirsch SR, Weinberger DR (eds), Schizophrenia. Oxford, Blackwell Science Ltd, pp 293-323

Weinberger DR (1999): Cell biology of the hippocampal formation in schizophrenia. Biol Psychiatry 45:395-402

Wilkinson LS, Killcross SS, Humby T, Hall FS, Geyer MA, Robbins TW (1994): Social isolation in the rat produces developmentally specific deficits in prepulse inhibition of the acoustic startle response without disrupting latent inhibition. Neuropsychopharmacology 10:61-72

Woerner MG, Pollack M, Klein DF (1973): Pregnancy and birth complications in psychiatric patients: A comparison of schizophrenic and personality disorder patients with their siblings. Acta Psychiat Scand 49:712-721

Wolf ME, White FJ, Hu X-T (1993): Behavioral sensitization to MK-801 (dizocilpine): Neurochemical and electrophysiological correlates in the mesoaccumbens dopamine system. Behav Pharm 4:429-442

Wood GK, Tomasiewicz H, Rutishauser U, Magnuson T, Quirion R, Rochford J, Srivastava LK (1998): NCAM-180 knockout mice display increased lateral ventricle size and reduced prepulse inhibition of startle. Neuroreport 9:461-466

Wu CL, Melton DW (1993): Production of a model for LeschNyhan syndrome in hypoxanthine phosphoribosyltransferase-deficient mice. Nature Gen 3:235-240

Yonezawa Y, Kuroki T, Kawahara T, Tashiro N, Uchimura H (1998): Involvement of gamma-aminobutyric acid neurotransmission in phencyclidine-induced dopamine release in the medial prefrontal cortex. Eur J Pharmacol 341(1):45-56

Young CE, Arima K, Xie J, Hu L, Beach TG, Falkai P, Honer WG (1998): SNAP-25 deficit and hippocampal connectivity in schizophrenia. Cereb Cortex 8:261-268

Zaharia MD, Kulczycki J, Shanks N, Meaney MJ, Anisman H (1996): The effects of early postnatal stimulation on Morris water-maze acquisition in adult mice: genetic and maternal factors. Psychopharmacology 128:227-239 